This item was submitted to Loughborough's Research Repository by the author.

Items in Figshare are protected by copyright, with all rights reserved, unless otherwise indicated.

\title{
The order and priority of research and design method application within an assistive technology new product development process: A summative content analysis of 20 case studies
}

\section{PLEASE CITE THE PUBLISHED VERSION}

http://dx.doi.org/10.1080/17483107.2017.1280547

\section{PUBLISHER}

(c) Taylor \& Francis

\section{VERSION}

AM (Accepted Manuscript)

\section{PUBLISHER STATEMENT}

This work is made available according to the conditions of the Creative Commons Attribution-NonCommercialNoDerivatives 4.0 International (CC BY-NC-ND 4.0) licence. Full details of this licence are available at: https://creativecommons.org/licenses/by-nc-nd/4.0/

\section{LICENCE}

CC BY-NC-ND 4.0

\section{REPOSITORY RECORD}

Torrens, George E.. 2019. "The Order and Priority of Research and Design Method Application Within an Assistive Technology New Product Development Process: A Summative Content Analysis of 20 Case Studies". figshare. https://hdl.handle.net/2134/24603. 


\title{
The order and priority of research and design method application within an assistive technology new product development process: A summative content analysis of 20 case studies.
}

\section{George Edward Torrens}

Senior Lecturer, Loughborough Design School, Loughborough University LE11 3TU United Kingdom. Email: g.e.torrens@lboro.ac.uk

\section{Implications for Rehabilitation}

The communication highlights a number of issues that have implication for those involved in assistive technology new product development:

- The study defined over 200 well-established research and design methods and design heuristics that are available for use by those who specify and design assistive technology products, which provide a comprehensive reference list for practitioners in the field;

- The review within the study suggests only a limited number of research and design methods are regularly used by industrial design focused assistive technology new product developers; and,

- Debate is required within the practitioners working in this field to reflect on how a wider range of potentially more effective methods and heuristics may be incorporated into daily working practice.

\begin{abstract}
Summative content analysis was used to define methods and heuristics from each case study. The review process was in two parts: 1) A literature review to identify conventional research methods; and, 2) a summative content analysis of published case studies, based on the identified methods and heuristics to suggest an order and priority of where and when were used. Over 200 research and design methods and design heuristics were identified. From the review of the 20 case studies 42 were identified as being applied. The majority of methods and heuristics were applied in phase two, market choice. There appeared a disparity between the limited numbers of methods frequently used, under ten within the 20 case studies, when hundreds were available.
\end{abstract}

\section{Keywords}

Industrial design, research and design methods, design heuristics, assistive technology, product design

\section{Introduction}

When working with healthcare professionals in the early 1990's, the author was challenged to 'prove' why the Assistive Technology (AT) product he had designed worked; not just in terms of functionality, but also its social function. It was at this 
point the author realised he did not have a pathway to provide the required validation, starting a career-long study into suitable ways to validate AT product design within the context of Industrial design.

This article provided some insights towards answering the need for practicing Industrial Designers to effectively apply design and validation methods and heuristics when working in the field of AT product design; providing a bridge between theory and practice. There is a further debate relating to the benefits of providing a detailed structure for design activities versus the constraints it might bring to creativity, but this is beyond the scope of this study.

In the1990's the medical model of healthcare (treatment of symptoms) was being superseded by the social model (treatment of the person). (Conway 2008) The healthcare professionals also applied an evidence-based approach to medical intervention and expected the same evidence of efficacy AT products. Efficacy was considered to be the combination of effectiveness of an intervention and its costeffectiveness.

To provide a fixed viewpoint for this review a definition is required for Industrial design and associated validation of efficacy. An Industrial Designer (ID) contributes to the social and cultural function, or value, by embedding cultural coding in a product or service, manipulating the viewer's or user's perceptions of it within the constraints of cost and time. Effectiveness may be validated through a mixed methods approach of qualitative and quantitative evaluation employing interview, observation, survey, product probes, comparison rating and eye tracking, force sensors, motion capture, galvanic resistance, all formally applied within research methods that include: task analysis, systems analysis and ethnography. AT product design is a subsection of Industrial design focusing on the provision of products (predominantly) that is used to increase, maintain or improve the functional capabilities of individuals with disability. (WHO 2016: 14) See Figure 1. 


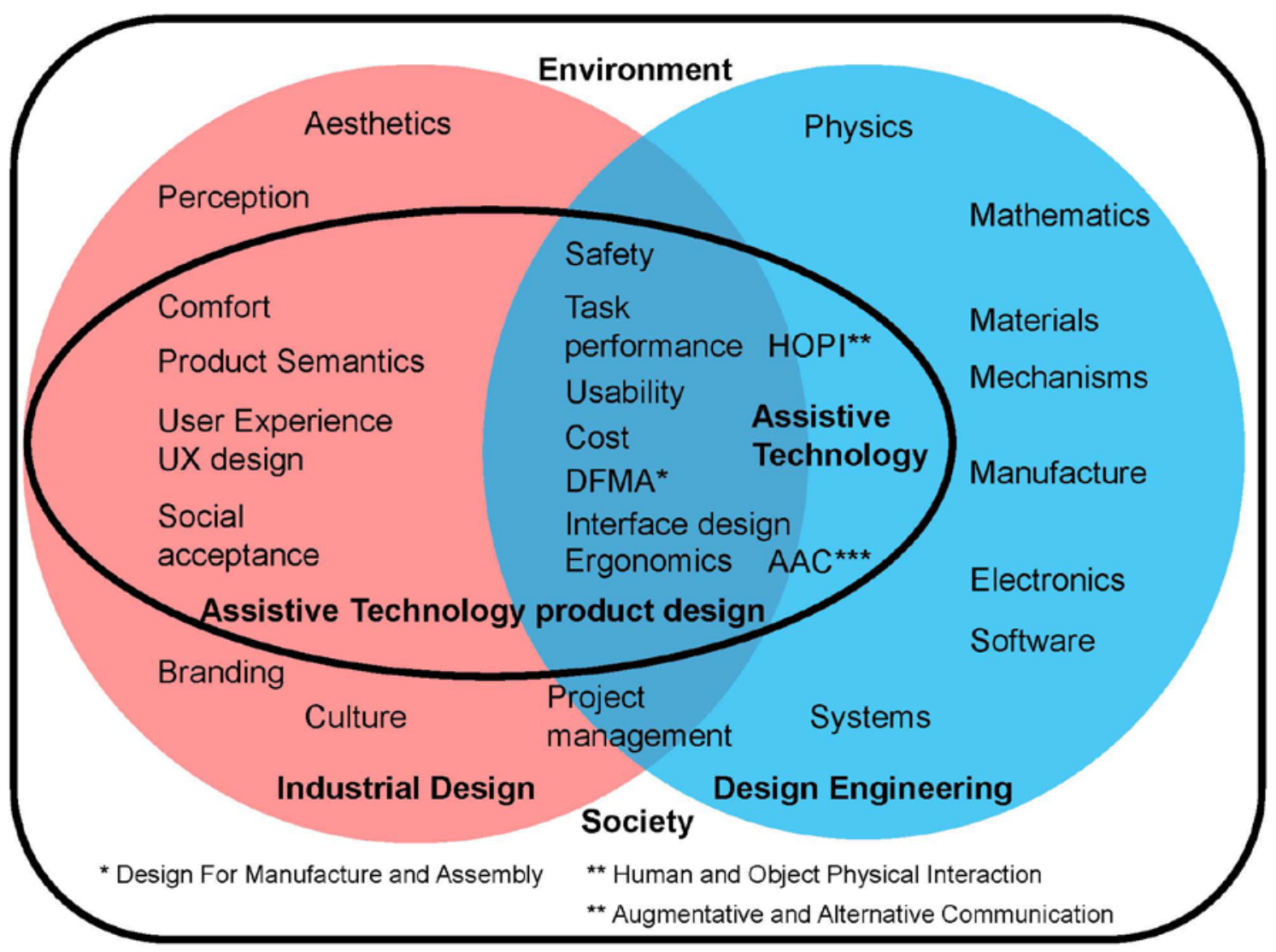

Figure 1. Assistive technology within Design and Engineering. (Torrens 2015)

The combination of social functionality and physical function within ID means that adoption of an engineering approach to product validation is not possible. In this context, social functionality is the individual and societal needs and aspirations for a product. The needs and aspirations may be aligned with Donald Norman's affordances (1999) or Patrick Jordan's four domains (2002). To enable validation beyond outcome, ID practitioners require a combination of both qualitative and quantitative research methods. Creswell (2009) and Plowright (2011) both advocate a mixed methods approach, which suits the needs of ID practitioners.

The application of research methods may be augmented by design methods and heuristics, which have been developed to enable an Industrial designer to develop a dialogue with their client, end users and stakeholders. The complexity of social and physical functionality embodied in a design solution is often presented as a 2D image or 3D object. Definitions were required to differentiate between research and design. Research methods were categorised under three main forms: exploratory; constructive; and, empirical research (Allison et al 1996: 6).

Design methods were defined as a systematic way of doing something within a sequence of operations actions or events that may be called a design process. (Jones 1970) In addition to systematic actions, the definition of a design method in this study includes applied knowledge or principles. The principles or rules offer structure to deductive reasoning within an evidence-based design decision-making 
process. The evidence used in a deductive reasoning design process may be shown through the service or artefact. The decisions made to realise the product may be critically reviewed using an inductive approach.

The application of techniques and use of heuristics in a timely sequence provide the operator with a simplified set of variables on which design decisions may be made, within the complexity of a real-world problem. (Cross 1989) Design heuristics were defined as mental short-cuts or rules applied to ease the cognitive load when making timely design decisions. (O'Flynn and Waldmann 2011: 112) Heuristics were considered to be rules often based on past experience and learned behaviours, (e.g. rule of thumb). They were also considered be a collective consensus of opinion on a specific set of variables. (Martin and Hanington 2012: 98) Martin and Hanington suggested heuristics could help in categorising, organising or prioritising. Heuristics might also be used to generate options from which design decisions may be made.

The application of design principles, alongside design heuristics, produce an effective way of doing things. Although an inductive approach may be taken, the use of principles (theory) enables a potentially reliable prediction of outcome. The authors experience has been that Industrial design validation still relies heavily on success of the product in the marketplace, particularly within AT product design.

This article was written from the viewpoint of applied science, rather than a narrative or critical reflection. Based on the author's experience, Industrial Designers are more familiar with this format than reflective texts, as much of their work is closely aligned with Engineering.

\section{Aim and objectives}

The aim of this article was to provide design practitioners with insights into the order and priority of research and design method and design heuristic application within a new product development process (NPD), focused on Assistive Technology (AT) products.

The objectives were to:

- Identify available research methods, design methods and heuristics from literature;

- Critically review available literature to identify unique methods and heuristics and minimise duplication of purpose;

- Review 20 published AT product development case studies to identify when these methods are applied;

- Define a critical pathway of method and heuristic application; and,

- Identify any other characteristics that may be AT product design specific.

\section{Summative content analysis}


Summative content analysis was used to define methods and heuristics from each case study. (Hsieh and Shannon 2005) Content analysis may be considered a derivative of Thematic analysis (Braun and Clarke 2006).

The study explored the application of methods and heuristics through identified keywords within twenty case studies. The keywords were derived from a literature review and placed within a known context and structure. Bounding of the literature review limited expectations and focused on providing material that was within the professional practice of Industrial design within the field of Assistive Technology product design.

The review process was in two parts: 1) The identification of conventional research methods; and, 2) summative content analysis of published case studies to identify the order and priority of where and when defined methods and heuristics were used. See Figure 2. Case study is a research method involving in-depth and detailed examination of a subject of study (the case), within related contextual conditions or environments. (Cohen et al 2007: 34)

\section{Literature Review}

To help bound the field of design and research to be covered, a number of limitations were placed on the review. The limitations were based on an initial review of available material across all areas, using the online software "Library Catalogue Plus" (Ex Libris, 2016), a meta-search engine. Keywords initially used were: "research methods, design methods, design heuristics, Industrial design, Product design, Assistive Technology, Inclusive design, Universal design, User centred design". The author found from the initial review that methods described in journal articles were often derivations or hybrids of conventional protocols. Articles and textbooks based in Engineering and Architecture brought a range of methods not usually applied by Industrial designers.

The focus of the main review was on the definition of existing and well-established research methods, design methods and heuristics. Methods and heuristics to be included were user-centred and human scale, hand-held or body-worn (including wheelchair accessories), which excluded predominantly engineering and architectural methods and heuristics relating to physical manufacturing, materials and systems. The context of the case studies was all from within the support and funding structures of United Kingdom (UK) based healthcare. Reference to other International healthcare structures and viewpoints were translated into or compared with a UK context. The terminology of definitions related to this field of Design discipline were from a UK context and perspective.

The design of medical products, such as those used in secondary care (Medical Hospitals) for example; interior design or architectural issues, such as accessibility and space design, was beyond the scope of this review. Similarly, issues of creativity and innovation were not considered in this review of methods for the pragmatic 
reasons of the available time and resource to the author. Design decision-making was discussed, but in the context of efficacy of method. The journals and textbooks that were included assumed some background knowledge of design or engineering processes.

There was no time limit placed on the publication date of textbooks or articles reviewed as some research methods, such as paired comparison, were first described nearly a hundred years ago. (Thurstone, 1927)

The emphasis on well-established methods and heuristics focused the review on textbooks, Theses and standards. Research articles and conference papers were considered to present new and innovative approaches to research and design methods and design heuristics. New approaches to the application of existing methods or novel developments were less likely to have been widely used or demonstrated as effective. Standards in this context were British Standards relating to Industrial Design and Assistive Technology/Inclusive design. These standards related to design management of a new product development process. 


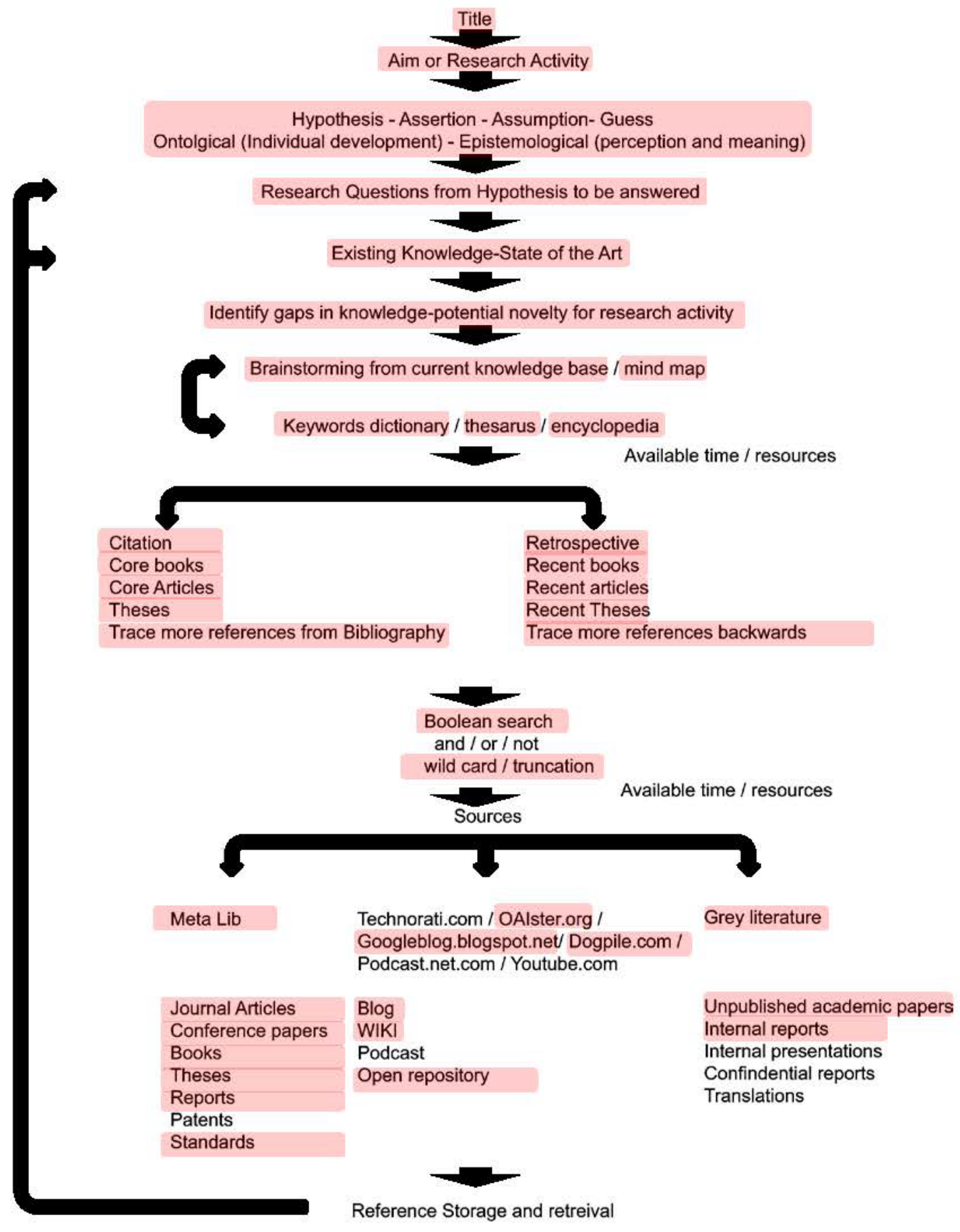

Ref works / End note / Excel / WWWebpage (hypertext linked)

Figure 2. Literature review pathway.

There was an iterative cycle of review, including data mining of authors of interest and reference lists from within articles and textbooks. The keywords used in the initial survey were used for the main survey, as they were found to provide a manageable number of references within the limitations of an individual reviewer.

A list of methods and heuristics was complied. The author's experience and professional connoisseurship in the field of Industrial and Product Design were used 
to make qualitative decisions about duplication of methods or heuristics from different sources. Methods and heuristics were initially identified by name, with each article or chapter checked to ensure they match the protocol conventions associated with them. Where not clearly defined the protocols described were used to identify the method or heuristic through matching to other similar descriptions in other texts, within the context of their application as a research or design tool.

\section{Summative content analysis of case studies}

The case studies were analysed to A) Identify methods and heuristics employed; and, $B)$ the point at which they were used during the design process described in the associated article or chapter.

Twenty case studies from the field of Assistive Technology product design were identified and selected from available sources, including Journal articles and textbooks. Ten were from the author, spanning a fifteen year period, with ten from other authors over the same period. Studies from other authors were chosen to match the level at which the ten author case studies were described: method only (Micro level); combined methods (Mezzo level); and, methodology or approach (Macro level).

Statistical validation of outcomes were mentioned in case studies, but not discussed in detail. They are not defined as a method in the literature review or thematic analysis outcome. The author's experience has been that the choice of statistical validation technique would be done with the advice of a statistician. The technique would be applied as part of the post-processing of data, a sub-section of a method.

The format of the British Standard BS7000-6: 2005 (British Standards 2005) was used to categorise and sequence a design process. These were mapped onto existing design references that defined a design process. The five phases of Martin and Hanington (2012) were through to best match on to the British Standard and a 'double-diamond' diagram of a new product development process promoted by the Design Council in the United Kingdom. (2016) See Figures 3 and 4.

The author considered that beyond stage 7 of the British Standard was effectively a repeat of the Martin and Hanington phase 1, within the context of Industrial design. For practical purposes, phase 1 of the Martin and Hanington phases was repeated in phase 5 of the table. This conclusion was based on the need to review the product launched in stage 7/end of stage 4 as a new product, defining new markets, insights and developing propositions to modify the existing design. The methods and heuristics appropriate for this task are the same or similar to those in phase 1 . More specific methods for phase 5 from engineering and business management were not included, as they were considered outside the focus on ID practice.

The ten papers from the author were used to develop a template protocol for the analysis and the identification of keywords (specified methods and heuristics) within 
the text; the sections of a new product design process described in the case study; and, the points at which the methods and heuristics were used within the described design process.

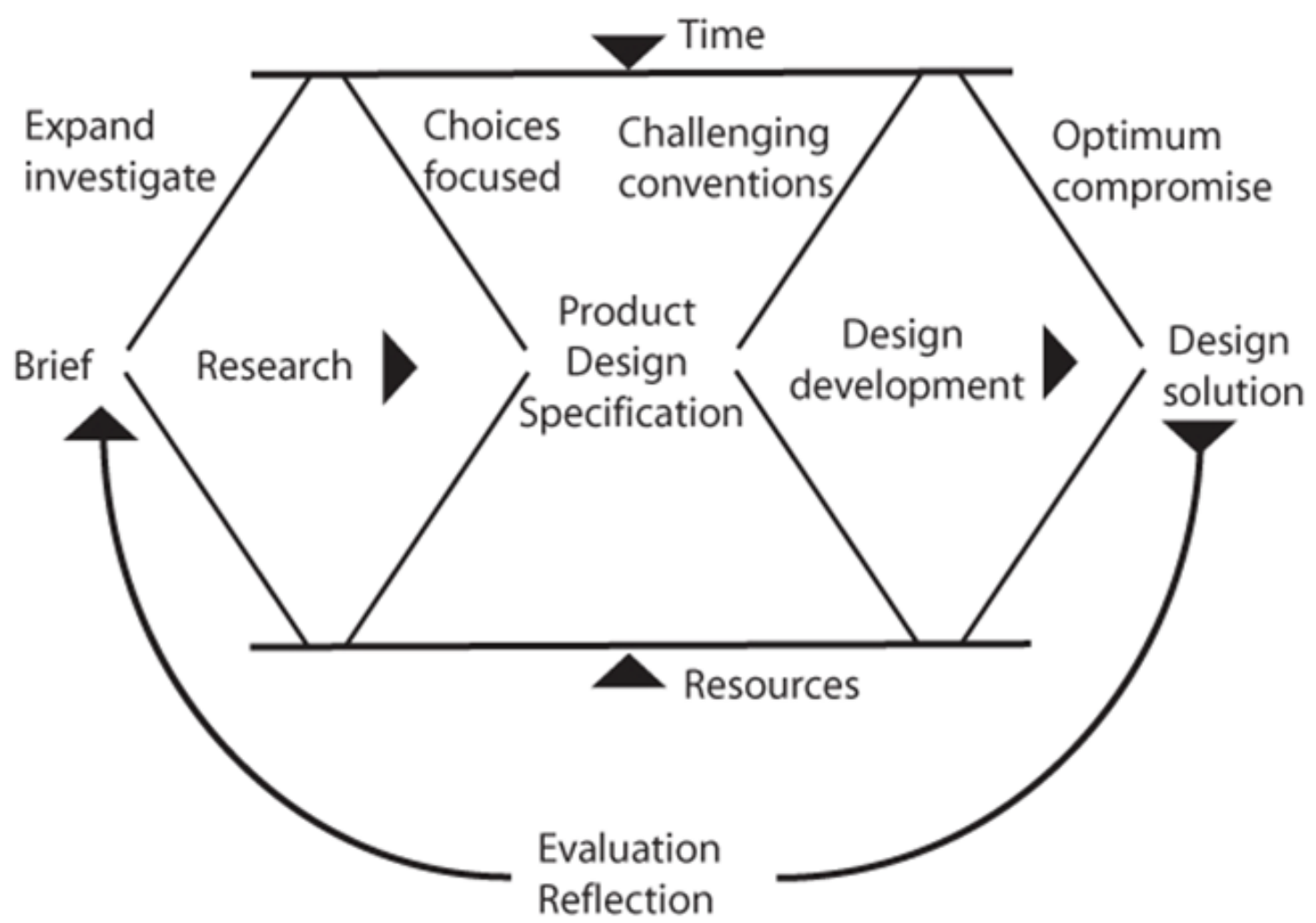

Figure 3. Design development process promoted by the Design Council (1986), modified by the author (Torrens 2012).

To minimise bias, the twenty case studies were reviewed by two operators, using the same protocol. The list of methods and heuristics were supplied to both operators, along with a short description of each of the Martin and Hanington phases. (See Table 1.) They were also supplied with a list of defined research methods, design methods and design heuristics from the literature review. (See Tables 1, 2. and 3.) The operators used Tables 1, 2, 3 and 4. to identify those used in each study and at what point in the five phases they were applied. One operator was the author, the other an administrator with a good working knowledge of design methods. Using an operator not fully immersed in design methods was to ensure the descriptions were reviewed on the content alone; to avoid the operator unintentionally 'filling in' any gaps using past experience of the methods.

The two reviews were compared to identify any anomalies or other differences between each reviewer's interpretations of each case study. If any differences were found, they were to be discussed and highlighted. Where one operator had identified a method or heuristic and not the other, the reasoning for identification was to be 
discussed and the element included or excluded. Due to constraints of time and resource consideration was not given to any excluded identified methods or heuristics being novel or a new category being needed. Where there was a difference of opinion in placement of method or heuristic within the five phases or multi-use phase the same format of discussion was to be applied to come to a decision on that element's position within the phases. The externalisation of operator reasons for choices made was also to resolve differences of interpretation.

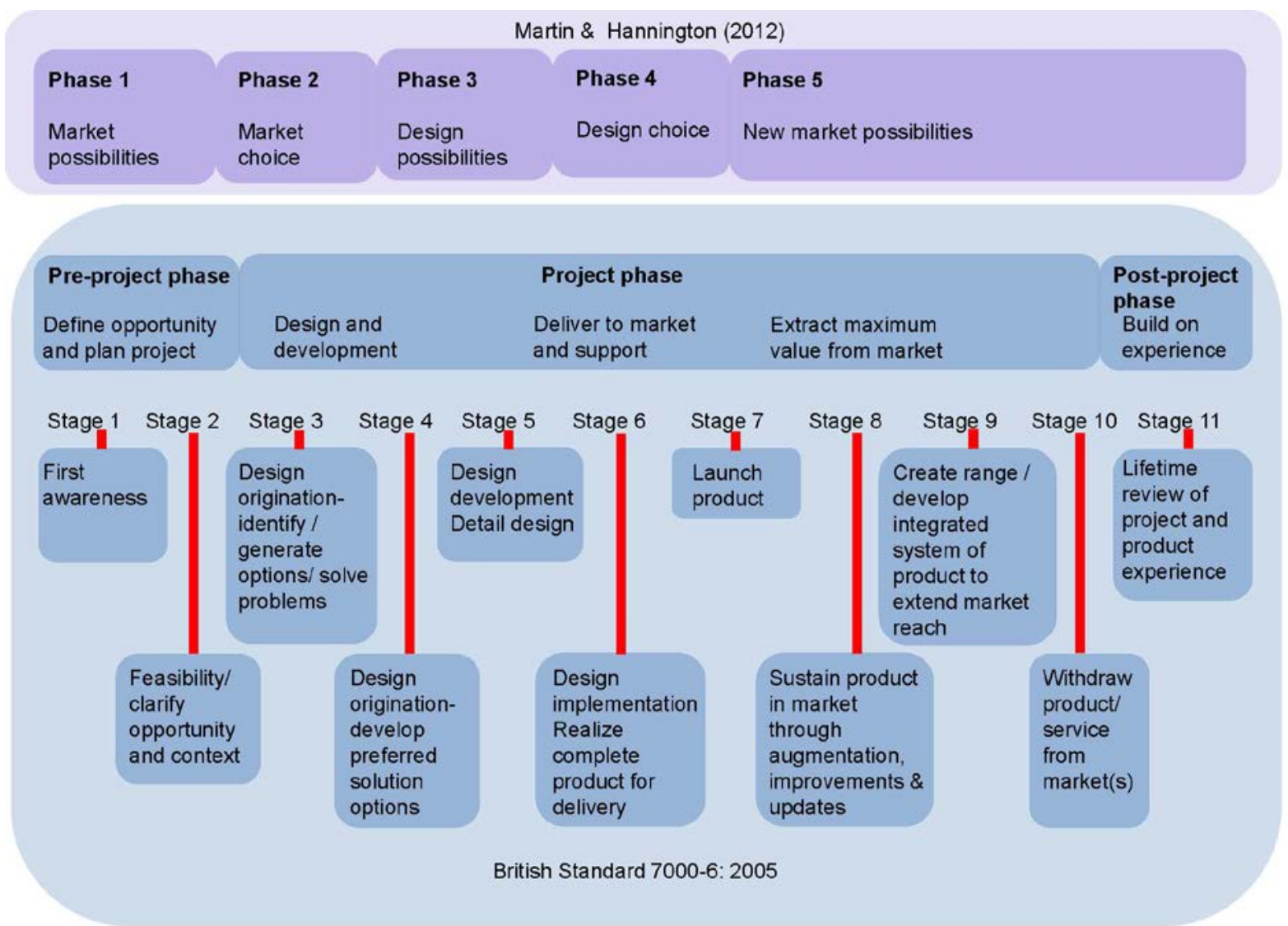

Figure 4. A comparison of the five phases of Martin and Hanington (2012) and the defined phases within the British Standard 'Managing inclusive design' (British Standard 2005).

A critical path analysis (Fondhal 1962) was then to be applied by the author to the identified methods and heuristics from the twenty case studies to group and order their application. (See Table 3.) 
Table 1. Description of Martin and Hanington five phases, based on the requirements of BS7000-6:2005.

\begin{tabular}{|c|c|c|c|c|}
\hline Phase 1 & Phase 2 & Phase 3 & Phase 4 & Phase 5 \\
\hline $\begin{array}{l}\text { Market } \\
\text { possibilities; } \\
\text { Planning, } \\
\text { scoping and } \\
\text { definition; project } \\
\text { parameters } \\
\text { explored and } \\
\text { defined; first } \\
\text { awareness; } \\
\text { feasibility, clarify } \\
\text { opportunity and } \\
\text { context; insights; } \\
\text { gain consensus. }\end{array}$ & $\begin{array}{l}\text { Market choice; } \\
\text { exploration, } \\
\text { synthesis and } \\
\text { design } \\
\text { implication; } \\
\text { immersive } \\
\text { research and } \\
\text { design } \\
\text { ethnography; } \\
\text { design } \\
\text { origination- } \\
\text { identity, Brand, } \\
\text { generate } \\
\text { propositions/solve } \\
\text { problems; } \\
\text { propositions; } \\
\text { Ideation; } \\
\text { generation of } \\
\text { product design } \\
\text { specification; } \\
\text { validate with } \\
\text { market; individual } \\
\text { and consensus. }\end{array}$ & $\begin{array}{l}\text { Design } \\
\text { possibilities; } \\
\text { concept } \\
\text { generation, early } \\
\text { prototyping } \\
\text { iteration, } \\
\text { participatory and } \\
\text { generative design } \\
\text { activities; design } \\
\text { origination- } \\
\text { develop preferred } \\
\text { solution options; } \\
\text { design } \\
\text { development; } \\
\text { detail design; } \\
\text { validate with } \\
\text { market; gain } \\
\text { consensus. }\end{array}$ & $\begin{array}{l}\text { Design choice; } \\
\text { evaluation, } \\
\text { refinement and } \\
\text { production; } \\
\text { iterative testing } \\
\text { and feedback; } \\
\text { design } \\
\text { implementation; } \\
\text { realise complete } \\
\text { product for } \\
\text { delivery; testing } \\
\text { and validation to } \\
\text { standards and } \\
\text { industry } \\
\text { guidelines; } \\
\text { Launch product. }\end{array}$ & $\begin{array}{l}\text { New market } \\
\text { possibilities; } \\
\text { monitoring of } \\
\text { product in } \\
\text { market; } \\
\text { awareness of } \\
\text { new markets; } \\
\text { feasibility, clarify } \\
\text { opportunity and } \\
\text { context; insights; } \\
\text { sustain market } \\
\text { through } \\
\text { improvement; } \\
\text { create } \\
\text { range/develop } \\
\text { integrated } \\
\text { systems of } \\
\text { product to extend } \\
\text { market reach; } \\
\text { lifetime review } \\
\text { and product } \\
\text { experience. }\end{array}$ \\
\hline
\end{tabular}

\section{Results}

Over 150 references were reviewed in the Literature review (see Bibliography). A consensus on identification could be made for many of the conventional research methods, such as observation, literature review and interview as they were described in multiple textbooks. It was more difficult to identify methods and heuristics that were AT product design specific, as they were less frequently reported.

Following the literature review, 10 references in total were used as the descriptors for all the methods. Martin \& Hanington (2012), Lidwell, Holden \& Butler (2003) and Wilson \& Coreltte (2015) provided the bulk of the descriptions, with Papanek (1974). A description of Delphi Study from Green (2014), Benchmarking, (Edwards 2016, Tutton 2009) and Grounded theory (Bryman: 401) were included along with AT specific ID methods from the author (Torrens 2013: 233-248, Torrens and Gyi 1999: 217-226). The majority of methods and heuristics were also defined in other texts, but this group provided the maximum number of descriptions for least number of references from which to refer. Where journal articles had been referenced, or a Thesis in the case of the Delphi study, it was to apply the most accessible and complete definition of the method or heuristic.

Operators looked for the defined methods and heuristic titles within the text. This was equivalent to keywords within a generic summative content analysis protocol. 
They then reread the text to compare the task to which the identified method or heuristic was being applied to match them to the correct title in the list within Tables 2, 3 and 4. The second reading provided a contextual check for the operator relating to their choice. Appendix 1 shows the intermediate step of methods and heuristics identification and ordering against each case study prior to summary in Table5.

When comparing the two reviews the main difference was that the practitioner immersed in design defined more methods than the operator from a non-design background. From discussion, the design practitioner had defined activities that were not explicitly described.

Table 2. Shows 59 defined research methods.

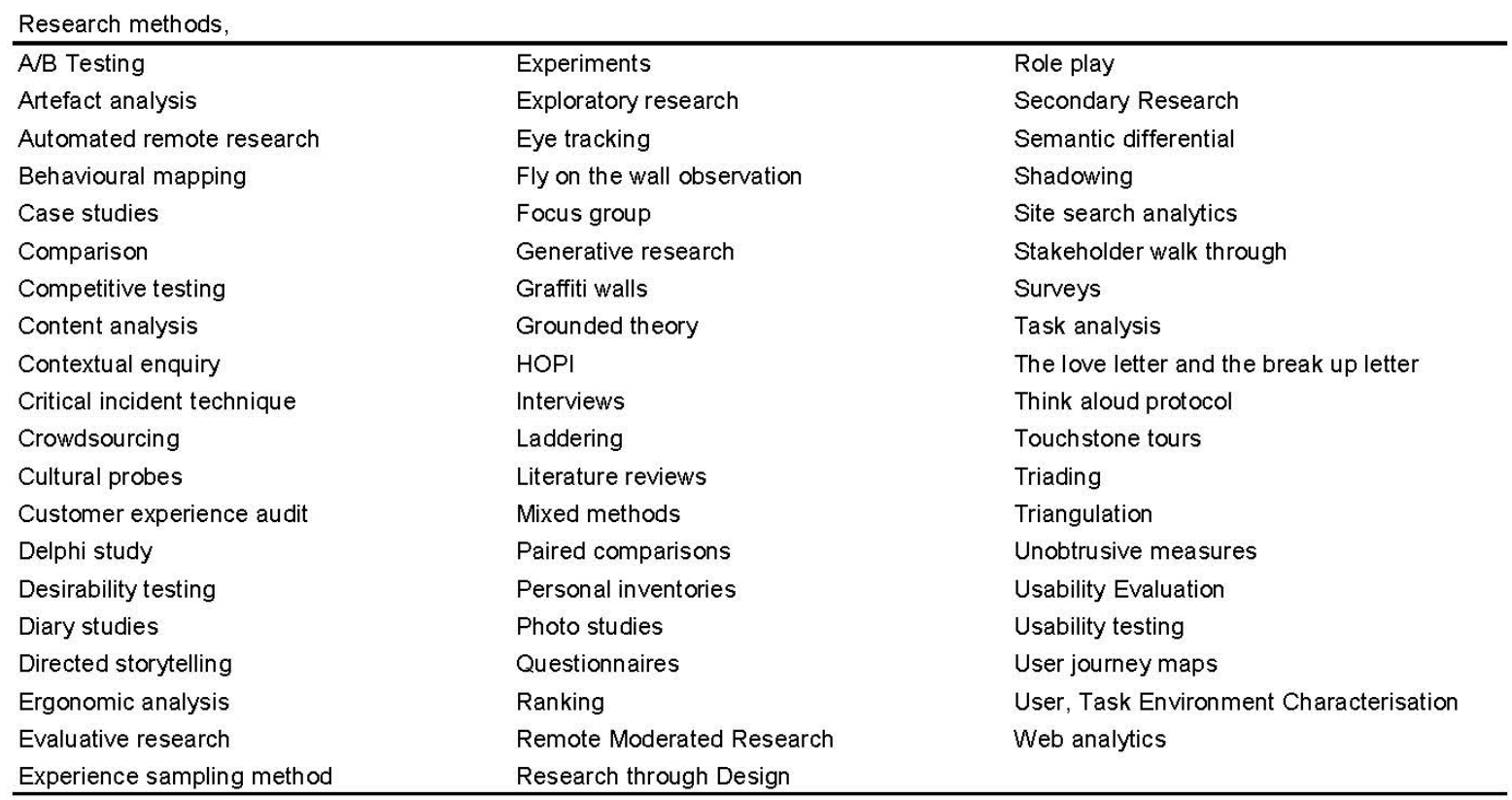

From the 20 case studies 42 methods and heuristics in total were identified. Of these 20 were research methods; 17 were design methods; and, 5 were design heuristics. See Table 5. The Table also shows the second phase of review, which was to place the methods and heuristics within the defined five phases or multi-use phase.

Steps were taken to identify the phase into which each method or heuristics would be placed involved re-reading each case study. The phases each case study described were considered and used to then place the method or heuristic in the appropriate phase. 
Table 3. Shows 28 defined design heuristics.

Design heuristics

\begin{tabular}{lll}
\hline $80 / 20$ rule/ Pareto's principle & Five-hat racks & Picture cards \\
AEIOU & Flexibility usability trade-off & Scenario description swim lanes \\
Brainstorm graphic organisers & Heuristic evaluation & Stakeholder maps \\
Card sorting & Hierarchy of needs & Thematic networks \\
Cognitive mapping & Kano analysis & Usability report \\
Cognitive walk-through & Key Performance Indicators & Value opportunity analysis \\
Collage & KJ technique & Weighted matrix \\
Cost-Benefit & Mental model diagrams & Word Clouds \\
Depth of processing & Mind mapping & \\
Elito method & Personas & \\
\hline
\end{tabular}

Table 4. Shows 117 defined design methods.

Design methods

\begin{tabular}{|c|c|c|}
\hline Accessibility & Factor of Safety & Participatory design \\
\hline Advance organiser & Feedback loop & Performance load \\
\hline Aesthetic usability effect & Fibonacci sequence & Performance vs Preference \\
\hline Affinity Diagramming & Figure-ground relationship & Picture superiority effect \\
\hline Affordance & Fitt's law & Progressive disclosure \\
\hline Alignment & Forcing new thinking patterns & Prospect refuge \\
\hline Archetypes & Forgiveness & Prototyping \\
\hline Attractiveness of bias & Form follows function & Proximity \\
\hline Baby-face bias & Framing & Readability \\
\hline Benchmarking & Garbage in garbage out & Recognition over recall \\
\hline Bionics & Golden ratio & Redundancy \\
\hline Champion user & Good continuation & Rule of thirds \\
\hline Chunking & Gutenberg diagram & Satisficing \\
\hline Classical conditioning & Hick's law & Savanna preference \\
\hline Closure & Hierarchy & Scaling fallacy \\
\hline Codesign & Highlighting & Scenarios \\
\hline Cognitive dissonance & Iconic representation & Self-similarity \\
\hline Colour & Image boards & Serial position effects \\
\hline Common fate & Immersion & Shaping \\
\hline Confirmation & Interference effects & Signal to noise ratio \\
\hline Consistency & Inverted pyramid & Similarity \\
\hline Constancy & Iteration & Simulation exercises \\
\hline Constraint & Law of Pragnanz & Standardisation \\
\hline Control & Layering & Storyboards \\
\hline Creative tool kits & Legibility & Storytelling \\
\hline Defensible space & Lifecycle & Structural forms \\
\hline Design charette & Mapping & Symmetry \\
\hline Design ethnography & Mental model & Technology footprint \\
\hline Design workshops & Mimicry & Threat detection \\
\hline Development cycle & Mnemonic device & Three dimensional projection \\
\hline Empathic modelling & Modularity & Top-down lighting bias \\
\hline Entry point & Most average facial appearance effect & Uncertainty principle \\
\hline Errors & Normal Distribution & Uniform connectedness \\
\hline Evidence-based design & Ockham's Razor & Visibility \\
\hline Expectation effect & Operant conditioning & von Restroff effect \\
\hline Experience prototyping & Orientation sensitivity & Waist-to-hip ratio \\
\hline Expert Review & Parallel prototyping & Wayfinding \\
\hline Exposure effect & Participant observation & Weakest link \\
\hline Face-ism ratio & Participatory Action Research (PAR) & Wizard of $\mathrm{Oz}$ \\
\hline
\end{tabular}


Table 5. shows critical path analysis of the application of design research methods and heuristics within an AT product development.

\begin{tabular}{|c|c|c|c|c|c|c|c|c|c|}
\hline $\begin{array}{l}\text { Research methods, design methods and } \\
\text { design heuristics }\end{array}$ & 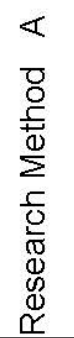 & 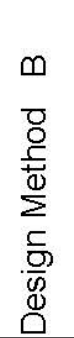 & 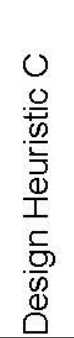 & $\begin{array}{l}\mathscr{1} \\
\infty \\
\\
0 \\
0 \\
\mathbb{D} \\
\frac{1}{\alpha}\end{array}$ & $\begin{array}{l}0 \\
\mathbb{N} \\
\mathbb{N} \\
\frac{\Sigma}{\alpha}\end{array}$ & $\begin{array}{l}0 \\
0 \\
\mathbb{D} \\
\frac{\mathbb{Z}}{\alpha} \\
\end{array}$ & 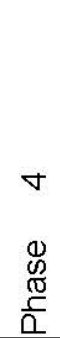 & $\begin{array}{l}0 \\
0 \\
0 \\
0 \\
0 \\
\frac{0}{0} \\
\frac{1}{0} \\
\overline{\bar{\alpha}}\end{array}$ & 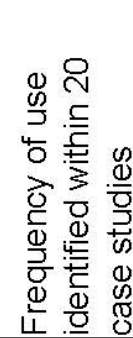 \\
\hline Design ethnography & & $\mathrm{B}$ & & 185 & & & & & 4 \\
\hline Empathic modelling & & $\mathrm{B}$ & & $1 \& 5$ & & & & & 4 \\
\hline Mental model & & $\mathrm{B}$ & & $1 \& 5$ & & & & & 4 \\
\hline Brainstorm graphic organisers & & & C & $1 \& 5$ & & & & & 3 \\
\hline Cultural probes & A & & & $1 \& 5$ & & & & & 1 \\
\hline Grounded theory & A & & & $1 \& 5$ & & & & & 1 \\
\hline Task analysis & $\mathrm{A}$ & & & & 2 & & & & 18 \\
\hline Usability Evaluation & A & & & & 2 & & & & 17 \\
\hline Experience prototyping & & $\mathrm{B}$ & & & 2 & & & & 13 \\
\hline Interviews & A & & & & 2 & & & & 11 \\
\hline Performance vs Preference & & $\mathrm{B}$ & & & 2 & & & & 11 \\
\hline Evaluative research & A & & & & 2 & & & & 6 \\
\hline Image boards & & $\mathrm{B}$ & & & 2 & & & & 6 \\
\hline Ranking & A & & & & 2 & & & & 5 \\
\hline Value opportunity analysis & & & $\mathrm{C}$ & & 2 & & & & 5 \\
\hline Desirability testing & A & & & & 2 & & & & 4 \\
\hline Role play & A & & & & 2 & & & & 3 \\
\hline Storyboards & & $\mathrm{B}$ & & & 2 & & & & 3 \\
\hline HOPI & A & & & & 2 & & & & 2 \\
\hline Codesign & & B & & & 2 & & & & 2 \\
\hline Modularity & & B & & & 2 & & & & 2 \\
\hline Artefact analysis & A & & & & 2 & & & & 1 \\
\hline Standardisation & & B & & & 2 & & & & 1 \\
\hline Thematic networks & & & $\mathrm{C}$ & & 2 & & & & 1 \\
\hline Surveys & A & & & & & 3 & & & 9 \\
\hline Questionnaires & A & & & & & 3 & & & 6 \\
\hline Personas & & & $\mathrm{C}$ & & & 3 & & & 1 \\
\hline Visibility & & $\bar{B}$ & & & & & 4 & & 11 \\
\hline Expert Review & & $\mathrm{B}$ & & & & & 4 & & 9 \\
\hline Comparison & A & & & & & & 4 & & 4 \\
\hline Paired comparisons & A & & & & & & 4 & & 1 \\
\hline Performance load & & $\mathrm{B}$ & & & & & 4 & & 1 \\
\hline Case studies & $\mathrm{A}$ & & & & & & & 6 & 20 \\
\hline Literature reviews & A & & & & & & & 6 & 20 \\
\hline Participant observation & & B & & & & & & 6 & 17 \\
\hline User, Task Environment Characterisation & A & & & & & & & 6 & 15 \\
\hline Mixed methods & A & & & & & & & 6 & 12 \\
\hline Focus group & A & & & & & & & 6 & 11 \\
\hline Stakeholder maps & & & C & & & & & 6 & 9 \\
\hline Participatory Action Research (PAR) & & B & & & & & & 6 & 7 \\
\hline Evidence-based design & & $\mathrm{B}$ & & & & & & 6 & 3 \\
\hline Benchmarking & & B & & & & & & 6 & 2 \\
\hline
\end{tabular}


The review from each operator was again compared as applied in the first review of titles. The operators discussed differences to resolve any issue of placement. The activity appeared more straightforward as the scope of each study had been defined along with keyword titles for methods and heuristics.

The outcome of the review identified that 6 methods and heuristics were used in phases $1 \& 5$; 18 were used in phase 2; only 3 in phase 3; and, 5 in phase 4.10 had been identified as being potentially used across all phases.

The frequency of application across all 20 case studies was used to prioritise the methods in each phase. The high frequencies of methods or heuristics applied could have been predicted for each phase: design ethnography, empathic modelling and mental models in phase $1 \& 5$; task analysis, usability evaluation and experience prototyping in phase 2; surveys, questionnaires in phase 3; visibility (methods of use clearly visible) and expert review in phase 4; and, literature review, participant observation and user, task, environment characterisation across all phases.

Of the 42 methods and heuristics, only 12 were used in more than half the studies. Nearly half of the methods and heuristics, 20, were used in less than 5 studies.

\section{Conclusions}

The study was based around opinions of a small number of individuals. Whilst valid as a discussion point, the outcomes would potentially be difficult to replicate from this initial study. The summative content analysis would appear to work well for this application and context. A consensus on the definition of methods and heuristics and their categorisation would help make the analysis more reliable; more deductive than inductive.

The literature review was an initial sorting of methods and heuristics. The literature review has provided a statement of the classification of research methods, design methods and design heuristics. There are similar generic classifications in the Martin and Hanington; Lidwell, Holden and Butler references; and, more specific classifications in references by Clarkson et al.

The similarities and differences between what was presented in the study and other available classifications should be debated. For example, visibility, as described by Lidwell et al (2003: 202), relates to systems that are more usable when they indicate their status, the possible actions that may be performed and the consequences of those actions. They cite Design of everyday things (Norman 1990) as the reference for this description. The interpretation by the operators of this design method when reviewing the case studies encompassed the communication of use. If considered in more detail, within context of phase, the range of design methods that were selected as communicating use could have been wider. However, there was a constraint of review time per method selection in this study. 
A consensus is required into which category each activity described should be placed, within the context of Industrial design practice and AT product design.

Many of the activities defined as design methods are currently describing principles to be applied by designers, rather than the steps taken in application. There is more required of design researchers and educators to define these steps for new and practising designers; to link theory and practice.

From the case studies reviewed the link between research methods and the design interventions they validate does not appear to be well defined. Further discussion and debate is required.

What can be taken from the information provided is that whilst there are hundreds of methods and heuristics available the majority of studies reviewed from the AT product design field appear to apply less than quarter, with the majority applying less than ten. The case studies did provide an outline of the section of a design process they described. However, the requirement to provide a detailed outcome within the word limit of a journal article has resulted in limited discussion to the methods and heuristics of interest. The majority of the 20 studies alluded to work outside the focus of the communication. Further work is required to communicate to ID practitioners in this field the research methods, design methods and design heuristics available for use within their design process.

Table 5 may be used as a 'Look-up table', effectively becoming a design heuristic. The placing of methods and heuristics within the context of a standardised design process as shown in Table 5 may be considered a positive step towards students and practitioners to be more confident in their choice for application.

There is a debate needed between academics and practitioners to provide an accessible and useful taxonomy of methods and heuristics for use by students and practitioners in industry. The current online resources such as Usabilitynet (Usabilitynet 2016), Inclusive Design Tool kit (Inclusive design tool kit 2016), Usability-NET (Usability-NET 2016), and EDeAN, (EDeAN 2016) go some way to providing this, but more explicit and detail descriptions of each method are required.

The author welcomes further discussion and debate to bridge the gap between design intervention, through application of design principles, and its validation using available research methods.

\section{Acknowledgements}

The author would like to thank Mrs Julie Torrens for taking part in the study as a volunteer operator. 


\section{Bibliography}

Agree, E.M., and Freedman, V.A., 2011, A quality-of-life scale for assistive technology: results of a pilot study of aging and technology, Physical Therapy, (91), 12, pp1780-1788.

Allison, B., O'Sullivan, T., Owen, A., Rice, J., Rothwell, A., Saunders, C., 1996. Research skills for students, Kogan Page, London.

Barker, C., Pistrang, N., Robert, E., 2002. Research methods in clinical psychology: an introduction for students and practitioners (2nd ed), John Wiley \& Sons, Chichester.

Bazeley, P., 2007. Qualitative data analysis with NVIVO, Sage, London.

Bernsen, J., 1986. Design, the problems comes first, Danish design council, Copenhagen.

Birley, G., and Moreland, N., 1998. A practical guide to academic research, Taylor \& Francis, London.

Black, K. and Williamson, D., 2011. Designing inclusive physical activities and games. Design for sport. Farnham, UK: Gower.

Bourner, T., 1996. The research process: four steps to success. In: Greenfield, T., (ed), Research methods: guidance for postgraduates. Arnold, London.

Bramston, D., 2009. Idea searching, Basics in product design series, Thames Hudson, London.

Bray, J., Wright, S., (eds), 1979. The use of technology in the care of the elderly and the disabled: for the Commission of the European Communities, Pinter, London.

British standard, 2002. BS EN ISO 9999:2002. Technical aids for persons with disabilities-Classification and terminology.

British standard, 2005. BS7000-6:2005, Design Management systems. Managing inclusive design. Guide.

British standard, 2011. BS EN ISO 9999:2011. Assistive products for persons with disabilities-Classification and terminology.

Bruce, C., 1994. Supervising literature reviews. In: Zuber-Skerritt, O., Ryan, Y., (eds), Quality in postgraduate education. Kogan Page, London.

Bryman, A., 1988. Quantity and Quality in social research, Routledge, Abingdon.

Bryman, A., 2004. Social research methods, $\left(2^{\text {nd }}\right.$ ed), Oxford University Press, Oxford. pp401. 
Bryman, A., and Cramer, D., 1990. Qualitative data analysis for social scientists, Routledge, Abingdon.

Burns, R.B., 2000. Introduction to research methods, Sage, London.

Buxton, B., 2007. Sketching user experiences, getting the design right and the right decision, Morgan Kaufman, San Francisco.

Cadamuro, A., 2013. What remains? Strategy creativity series, Design Academy, Eindhoven.

Choi, Y.M. and Sprigle, S.H., 2011. Approaches for evaluating the usability of assistive technology product prototypes. Assistive Technology, 23(1), pp.36-41.

Clarkson, J., Coleman, R., 2015. History of inclusive design in the UK, Applied Ergonomics, 46, (B), Elsevier, Amsterdam, pp 235-247.

Clarkson, J., Coleman, R., Hoskin, I., Waller, S., 2007. Inclusive design toolkit, Cambridge University press, Cambridge.

Cohen, L., Manion, L., Morrison, K., 2007. Research methods in Education (6th ed), Routledge, Abingdon.

Coleman, R., Clarkson, J., Dong, H., Cassim, J.,2007. Design for inclusivity: a practical guide to accessible, innovative and user centred design, Gower, Aldershot.

Conway, M., 2008. Occupational Therapy and inclusive design: principles for practice, Blackwells, Oxford.

Coolican, H., 2004. Research methods and statistics in Psychology, (4th ed), Hodder Arnold, London.

Creswell, J.W., 2009. Research design: Qualitative, Quantitative and mixed methods approaches, (3rd ed), Sage, Thousand Oaks.

Creswell, J. and Plano Clarke, V., 2007. Designing and conducting mixed methods research, Sage, Thousand Oaks.

Crilly, N., 2005. Product Aesthetics, representing designer intent and consumer response, Thesis (PhD), Cambridge University Press, Cambridge. Available from: (http://publications.eng.cam.ac.uk/326484/), Accessed [2/09/2016]

Covington, G.A., Hanah, B., 1997. Accessing by design, John Wiley \& Sons, New York.

Crimp, M., 1990. The market research process (3rd ed), Prentice Hall, Hemel Hempstead.

Christophersen, J. and Norske stats husbank. 2002. Universal design: 17 ways of thinking and teaching. Husbanken, Oslo 
Cross, N., 1972. Design participation, Academy, London.

Crozier, R., 1994. Manufactured pleasures, physiological responses to design, Manchester University Press, Manchester.

Cushman, W.H., Ronsenberg, D.J., 1991. Advances in human factors/ Ergonomics, 14 human factors in product design, Elsevier, New York.

Dant, T., 1999. Material culture in the social world, Open University Press, Buckingham.

Demirbilek, O. and Demirkan, H., 2004. Universal product design involving elderly users: a participatory design model. Applied ergonomics, 35(4), pp.361-370.

Dominic, P., Demel, J., Lawbaugh, W., Freuler, R.J., Kinzel, G.L., Fromm, E., 2001. Tools and tactics of design, John Wiley \& sons, New York.

Dormer, P., 1994. The art of the maker, skill and its meaning in art, craft and design, Thames and Hudson, London.

Duarte, N., 2010. Resonate, present visual stories that transform audiences, John Wiley \& Sons, New Jersey.

EDeAN, 2016. EDeAN, (Online), Available from: (http://www.edean.org/), Accessed [2/09/2016]

Edel, D.H., 1967. Introduction to creative design, Prentice Hall.

Edwards, C. ed., 2016. The Bloomsbury Encyclopaedia of Design. Bloomsbury Academic. P158

Eriksson, J., 1998. Planning of environments for people with physical disabilities using computer aided design, University of Lund Press, Lund.

Evans, B., Powell, J., Talbot, R.,1982. Changing design, John Wilesy \& Sons, Chichester.

Eysensk, M.W., Keane, M.T., 2005. Cognitive psychology, student handbook, (5th ed), Psychology Press, Hove.

Fábio, R., Zilli, G.M., Sebben, D. and de Sousa, A.H., 2014. A Case Study on Assistive Technology for Visual Impairment Individuals: Adaptations in Household Appliances. Journal of Control, Automation and Electrical Systems, 25(2), pp.228236.

Fink, A., 2010. Conducting Research Literature Reviews: From the Internet to Paper, (3rd ed), Sage, London.

Fondahl, J.W., 1962. A non-computer approach to the critical path method for the construction industry. Online. Available from: 
(https://babel.hathitrust.org/cgi/pt?id=mdp.39015000453970;view=1up;seq=9) [Accessed: 1/08/2016]

Furr, R.M., and Bacharach, V.R., 2014. Psychometrics: an introduction, (2nd ed), Sage, thousand Oaks.

Gardner, L., Powell, L. and Page, M., 1993. An appraisal of a selection of products currently available to older consumers. Applied ergonomics, 24(1), pp.35-39.

Garner, S., 2008. Writing on Drawing: Essays on drawing practice and research, Intellect, Bristol.

Goldsmith, S., 1963. Designing for the disabled, (3rd ed) fully revised, RIBA, London. Gorman, K.P., 1998. Qualitative research for the information professional: a practical handbook (2nd ed), Facet, London.

Gray, C., Malins, J., 2004. Visualizing research, a guide to the research process in art and design, Ashgate, Farnham.

Green, W.S., Jordan, P.W., 1999. Human factors in product design, current practice and future trends, Taylor \& Francis, London.

Green, R.A., 2014. The Delphi technique in educational research. SAGE Open, 4(2), p.2158244014529773.

Greer, B., Mulhern, G., 2002. Making sense of data and statistics in psychology, Palgrave, Basingstoke.

Guest, G., MacQueen, K., Namey, E., 2012. Applied Thematic Analysis, Sage, Thousand Oaks.

Hammersley, M., 1992. What's wrong with ethnography?: methodological explorations. London: Routledge.

Hayes, S., Stidder, G., 2003. Equity and Inclusion in physical education and sport, Routledge, Abingdon.

Handicapped Persons Research Unit, 1984. The concerned technology, electronic aids for those with special needs, Handicapped Persons Research Unit, Newcastle upon Tyne Polytechnic, Newcastle upon Tyne.

Hart, C., 2002. Doing a literature search: Releasing the social science research imagination, Sage, London.

Hass, U., Brodin, H., Andresson, A., Persson, J., 1997. Assistive technology selection: A study of participation of users with rheumatoid arthritis, IEE Transactions on Rehabilitation Engineering (5), 3. pp-263-275. 
Hawkes, B., and Abinett, R., 1984. The engineering design process, Pitman, Wellington.

Hoffmeester, K., and ed Charon de Saint Germain, E., 1998, Presence, New media for older people, Netherlands Design Institute, Amsterdam.

IDEO, 2011. Human centred design toolkit, IDEO, Palo Alto.

Inclusive design tool kit, 2016. Inclusive design tool kit, (online) Available from: (http://www.inclusivedesigntoolkit.com/betterdesign2/), Accessed: [2/09/2016]

Jones, J., 1970. Design methods: seeds of human futures, Wiley-Interscience, London.

Jones, J.C., 1984. Essays in design, John Wiley \& Sons, Chichester.

Jones, J.C., 1991. Designing designing, Architecture design and technology Press, London.

Jordan, P.W., 2000. Designing pleasurable products, Taylor \& Francis, London.

Jordan, P.W., 2002. How to make brilliant stuff that people love and big money out of it, John Wiley \& Sons, Chichester.

Jordan, P.W., 2002. Designing pleasurable products: An introduction to the new human factors. CRC press.

Kairy, D., Rushton, P.W., Archambault, P., Pituch, E., Torkia, C., El Fathi, A., Stone, P., Routhier, F., Forget, R., Demers, L. and Pineau, J., 2014. Exploring powered wheelchair users and their caregivers' perspectives on potential intelligent power wheelchair use: a qualitative study. International journal of environmental research and public health, 11(2), pp 2244-2261.

Karwowski, W., Soares, M., Stanton, N., (eds), 2011. Human factors and ergonomics in consumer product design: Uses and Applications, Taylor \& Francis, Boca Ranton.

Karwowski, W., Soares, M., Stanton, N., (eds), 2011. Human factors and ergonomics in consumer product design: Methods and Techniques, Taylor \& Francis, Boca Ranton.

Keates, S., Clarkson, P.J., Harrison, L.A. and Robinson, P., 2000, November. Towards a practical inclusive design approach. In Proceedings on the 2000 conference on Universal Usability. ACM. pp45-52.

Keates, S., Clarkson, J., 2004. Countering design exclusion: an introduction to inclusive design, Springer Verlag, London. 
Kim, H.K., Han, S.H., Park, J. and Park, J., 2016. The interaction experiences of visually impaired people with assistive technology: A case study of smartphones. International Journal of Industrial Ergonomics, 55. pp.22-33.

Kirkwood, B.R., 1998, Essentials of Medical Statistics, Blackwell Science, Onsey Mead.

Klein, B., 1976. Design matter, Secker and Warburg, London.

Kroemer, K.H.E., Grandjean, E., 2000. Fitting the task to the human (5th ed), a textbook occupational ergonomics, Taylor \& Francis, London.

Kumar, S., 2001. Biomechanics in ergonomics, Taylor \& Francis, London.

Kuniavsky, M., 2003. Observing the user experience: a practitioners guide to user research, Morgan Kaufmann, San Francisco.

Neville, T.M., Henry, D.B., Neville, B.D., 2002. Science and technology research writing strategies for students, Scarecrow Press, Maryland.

Noble, I., Bestley, R., Visual Research: An introduction to research methodologies in graphic design, AVA, Case Postel.

Norman, D.A., 1999. Affordance, conventions, and design. Interactions, 6(3). pp.3843.

Norman, D.A., 2004. Emotional design, why we love (or hate) everyday things, Basic books, New York.

Norman, D.A., 2007. The design of future things, Basic books, New York.

Norman, D.A., 2002. The design of everyday things, Basic books, New York.

Langford, J., McDonagh, D., 2003. Focus groups supporting effective product development. Taylor \& Francis, London.

Laurel, B., (ed), 2003. Design research methods and perspectives, MIT Press, Cambridge MA.

Leahy, J., 2013. Target consumer involvement, an integral part of successful new product development, Research Technology Management, July-August, pp52-58.

Lidwell, W., Holden, K., Butler, J., 2003. Universal principles of design: 100 ways to enhance usability, influence perception, increase appeal, make better design decisions, and teach through design, Rockport, Gloucester.

Loughborough University, 2014. Ethical advisory committee, Ethics Approvals (Human Participants) Sub-committee, Loughborough University, Loughborough. Available at: (http://www.lboro.ac.uk/committees/ethics-approvals-humanparticipants/), Accessed [26/08/2014]. 
Loughborough University, 2014. References and citations, Loughborough University, Loughborough. Available at:

(http://www.lboro.ac.uk/services/library/skills/topicslist/topic---references-andcitations.html), Accessed [09/04/2015].

Macia, J.L., Plasencia, O.T., 2007. Subjective experience gathering techniques for interaction design: subjective psychological exploration techniques based in the constructivism paradigm for informational and inspirational purposes, University of Cataluña.

Mackenzie, C., Iberall, T., 1994. The grasping Hand: advances in Psychology, 104, Elsevier, Amsterdam.

McDonagh, D., Hekkert, P., van Erp, J., Gyi, D., (eds), 2004. Design and emotion, Taylor \& Francis, London.

Margolin, V., 1984. Design discourse, History. Theory. Criticism, University of Chicago Press, Chicago.

Martin, B., Hanington, B., 2012. Universal methods of design: 100 ways to research complex problems, develop innovative ideas, and design effective solutions, Rockport, Beverly.

Milton ,A., Rogers, P., 2013. Research methods for product design, Laurence King, London.

Moggeridge, B., 2007. Designing interactions, MIT Press, Cambridge, MA.

Milosevic, D., 2003. Project management toolbox: tools and techniques for the practicing project manager. John Wiley \& Sons, New Jersey

Morgan, D.L., 1997. Focus groups as qualitative research (2nd ed), Qualitative research methods series 16, Sage, Thousand Oaks.

Morrison, J., and Twyford, J., 1994. Design capability and awareness, Longman, Harlow.

Myers, D.G., 2002. Social Psychology (7th ed), McGrawHill, New York.

O'Flynn, R.K., Waldmann, T., 2011. Intelligence, creativity, and Descisions in Product Design. In Karwowski, W, Soares, M, M, Stanton, A, N, Eds, (ed) Handbook of Human Factors and Ergonomics in Consumer Products, CRC Press, pp.112.

Pacey, A., 1983. The culture of technology, MIT Press, Cambridge MA.

Papanek, V., 1974. Design for the real world: Human ecology and social change, Paladin, St Albans. 
Paredes, H., Fernandes, H., Martins, P. and Barroso, J., 2013, July. Gathering the Users' Needs in the Development of Assistive Technology: A Blind Navigation System Use Case. In International Conference on Universal Access in HumanComputer Interaction. Springer, Berlin Heidelberg pp. 79-88.

Pheasant, S., Haslegrave, C.M., 2006. Bodyspace, anthropometry, ergonomics and the design or work (3rd ed), Taylor \& Francis, London.

Pickering, M., 2001. Stereotyping, the politics of representation, Palgrave, Basingstoke.

Pirkl, J.J., 1994. Trandgenerational design, products for an ageing population, van Norstrand Rehinhold, New York.

Plos, O., Buisine, S., Aoussat, A., Mantelet, F., Duma, C., 2012. A Universalist strategy for the design of assistive technology, International Journal of Industrial ergonomics, 42, pp 533-541.

Plowright, D., 2011. Using Mixed Methods: Frameworks for an Integrated Methodology, Sage, Los Angeles.

Poggenpohl, S., and Sato, K., 2009. Design integrations: research and collaboration, Intellect, Bristol.

Potter, N., 1969. What is a designer: education and practice, a guide for students and teachers, Studio Vista, London.

Poulson D, Ashby M and Richardson SJ (eds.) (1996) USERfit. A practical handbook on user centred design for assistive technology. HUSAT Research Institute for the European Commission. Available from:

(http://www.education.edean.org/index. php?row=3\&filters=f16\&cardlndex=21). [Accessed 12/05/2015]

Poynor, R., 1998. Design without boundaries, visual communication in transition, Booth-Clibborn, London.

Pruitt, J. and Adlin, T., 2006. The persona lifecycle, keeping people in mind throughout product design, Elsevier, San Francisco.

Pugh, S., 1991. Total design, methods for successful product engineering, AddisonWesley, London.

Pullin, G., 2009. Design meets disability, MIT Press, Cambridge, MA.

Rexfelt, O., 2005. User-centred product development in practice, Chalmers University of Technology.

Robson, C., 2011. Real world research (3rd ed), John Wiley\& Sons, Chichester. 
Rose, G., 2001. Visual methodologies, Sage, London.

Rowe, P.R.W., (ed), 1995. Telecommunicaitons for all, COST 219, Commission of the European Union, Brussels.

Rowntree, D., 1981. Statistics without tears: A primer for non-mathematicians, Pelican, London.

Schifferstein, H.N., and Hekkert, P., (eds), 2008. Product experience, Elsevier, Kidlington.

Sekuler, R., and Black, R., 2002. Perception, McGraw-Hill, New York.

Shah, S.G.S., and Robinson, I., 2007. Benefits of and barriers to involving users in medical device technology development and evaluation, International Journal of Technology Assessment in Health Care, (23) 1, pp131-137.

Shinohara, K. and Tenenberg, J., 2009. A blind person's interactions with technology. Communications of the ACM, 52(8), pp 58-66.

Silverman D., 2000. Doing qualitative research: a practical handbook, Sage, London.

Silverman, D., 2006. Interpreting qualitative data (3rd ed), Sage, London.

Silverman, D., 2001. Interpreting qualitative data, methods for analysing talk, text and interaction (2nd ed), Sage, London.

Slack, L., 2006. What is product design?, Essential design handbooks, Rotovision, Mies.

Sparks, E., 2012. Advances in Military textiles and personal equipment, Woodhead, Oxford.

Stanton, N.A., and Young, M.S., 1999. A guide to methodology in ergonomics, designing for human use, Taylor \& Francis, London.

Steenbekkers, L.P.A., and van Beijsterveldt, C.E.M., (eds), 1998. Design-relevant characteristics of ageing user, Series ageing and ergonomics 1, Delft University press, Delft.

Stringer, E.T., 1999. Action Research (2nd ed), Sage, California.

Teddlie, C., and Tashakkori, A., 2009. Foundations of mixed methods research, integrating quantitative and qualitative approaches in the social and behavioural sciences, Sage, Thousand Oaks.

Thackara, J., 2006. In the bubble: designing in a complex world, MIT press, Cambridge MA.

The Design Council, 1995. Definitions of Design, Design Council, London. 
The Design Council, 1986. Royal Designers on design, Design Council, London.

The Design Council, 1986. A study of design process, Design Council, London. Available at:

(http://www.designcouncil.org.uk/sites/default/files/asset/document/ElevenLessons_ Design_Council\%20(2).pdf), Accessed [14/08/2016].

Thurstone LL. 1927. A law of comparative judgment. Psychological Review, 34. pp 273-286.

Tichauer, E.R., 1978. The biomechanical basis of ergonomics, anatomy applied to the design of work situations, John Wiley \& Sons, New York.

Torrens, G. 2000. Understanding the product user: The implementation of a usercentred design approach by student industrial designers when designing for elderly and disabled people, The Design Journal, 3, (1), Bloomsbury (formerly Berg), London. pp15-330

Torrens, G., McDonagh-Philp, D., Newman, A., 2001. Getting a grip, Ergonomics in Design: The quarterly of Human Factors Applications, 9 (2), pp7-13

Torrens, G.E., 2015. . An evaluation of the potential order and priority of research methods, design methods and design heuristics within an Assistive Technology new product development process, Thesis (PhD), Available from:

(https://dspace.lboro.ac.uk/dspace-jspui/bitstream/2134/18588/1/Thesis-2015Torrens.pdf), Accessed [2/09/2016].

Torrens, GE., 2012. Assistive Technology product to Universal design: A way forward, Design For All India, 7(7), pp.182-205.

Torrens, G.E. 2011. Universal Design: empathy and affinity. In Karwowski, W, Soares, M, M, Stanton, A, N, Eds, (ed) Handbook of Human Factors and Ergonomics in Consumer Products, CRC Press, pp.233-248.

Torrens GE, 1998. Design for Ageing and disability at Key Stage 4: An introduction to the nature of designing, available teaching materials and resources, National Association for Design Education (NADE) Journal 2 December

Torrens, G.E. and Gyi, D.E., Towards the integrated measurement of hand and object interaction, Proceedings of the 7th International Conference on Product Safety Research , US Consumer Product Safety Commission , Washington, USA, 1999, pp 217-226

Torrens, G.E., Hann, J., Webley, M., Joy, J. and Sutherland, I.A., 2000. Hand performance assessment of ten people with rheumatoid arthritis when using a range of specified saucepans, Disability and Rehabilitation, 22 (3), pp 123-133 
Torrens, G.E., Marshall, R., Burkitt, J. and Kay, G., 1996. Using modularity to produce more competitive assistive technology products, Proceedings of the 13th Irish Manufacturing Committee, Limerick, Ireland, pp 797-804

Torrens, G.E., and Newton, H., 2013. Getting the Most from Working with Higher Education: A review of methods used within a participatory design activity involving KS3 special school pupils and undergraduate and post-graduate industrial design students., Design and Technology Education: an international journal, 18 (1), pp 5871

Torrens, G.E. and Smith, N.C.S., 2013. Evaluation of an assistive technology product design using a paired comparisons method within a mixed methods approach: a case study evaluating preferences for four types of cutlery with 34 upper limb impaired participants, Disability and Rehabilitation: Assistive Technology, 8, (4). pp 340-347

Torrens, G.E., Williams, G., Huxley, R., 2001. Can you open this jar for me please: A pilot study of the physical nature of jar opening, Contemporary Ergonomics 2001, (ed) McCabe, P.T., Hanson, M.A. and Robertson, S.A., Taylor and Francis, Ergonomics Society Annual Conference, UK, Taylor \& Francis, London. pp83-89

Tutton, W.M., 2009. Exploring, evaluating and improving the development process for military load carrying equipment, Thesis (PhD), Available from: (https://dspace.lboro.ac.uk/dspacejspui/bitstream/2134/6032/5/2010@Tutton\%20Thesis_FINAL.pdf), Accessed [26/08/2014].

Usabilitynet, 2016. Usabilitynet (online) Available at:

(http://www.usabilitynet.org/home.htm), Accessed: [2/09/2016]

Usability-NET, 2016. Usability-NET, (online). Available at: (http://www.cap.Iboro.ac.uk/usability_net/), Accessed: [2/09/2016]

Visocky O'Grady, J. and Visocky O'Grady, K., 2006. Designer's research manual: succeed in design by knowing your clients and what they really need, Rockport, Beverly.

World Health Organisation, 2016. WHO global disability action plan 2014-2021. Better health for all people with disability. Online. Available from: (http://apps.who.int/iris/bitstream/10665/199544/1/9789241509619_eng.pdf?ua=1) [Accessed: 1/09/2016] 